\title{
Androgenetic Alopecia and its Association with Metabolic Syndrome: A Systematic Review and Meta-analysis
}

\author{
Leah Antoinette M. Caro-Chang, ${ }^{1}$ Mia Katrina R. Gervasio, ${ }^{1}$ and Claudine Yap-Silva ${ }^{1}$ \\ ${ }^{1}$ Section of Dermatology, Department of Medicine, Philippine General Hospital, University of the Philippines Manila \\ ${ }^{2}$ Section of Dermatology, Department of Medicine, College of Medicine and Philippine General Hospital, University of the Philippines Manila
}

\begin{abstract}
Objectives. The study aimed to confirm the association between androgenetic alopecia (AGA) and Metabolic Syndrome (MetS). It also aimed to determine if early-onset AGA among males and AGA among females increases the risk of developing MetS, and if severity of AGA increases the odds of developing MetS.
\end{abstract}

Methods. Observational studies from electronic databases were selected by the consensus of three independent review authors. The Newcastle-Ottawa Scale for assessing the quality of non-randomized studies in meta-analysis was used. Statistical analyses were accomplished using Review Manager software.

Results. A total of 11 case-control studies, one prospective cohort study, and five cross-sectional studies were selected. In the meta-analysis of ten case-control studies and three cross-sectional studies (3840 participants), AGA was significantly correlated with MetS (OR 2.59, 95\% Cl 1.51 to 4.44; $\mathrm{p}<0.0005$ ). Early-onset AGA among males (<35 years old) showed significant association (OR 3.69, 95\% Cl 2.15 to 6.33; $\mathrm{p}<0.00001$ ). AGA among females also increased the odds of developing MetS (OR 5.59, 95\% Cl 2.06 to 15.12; $p<0.0007$ ). Moderate to severe AGA in males, Norwood-Hamilton IV or higher, was also significant (OR 1.65, 95\% CI 1.12 to 2.42; $p=0.01$ ). The same trend was noted for females with Ludwig II and III (OR 5.82, 95\% Cl 2.54 to 13.34; $\mathrm{p}<0.00001$ ).

Conclusion. Although the pathophysiology still remains under investigation, the present study points to an association between AGA and MetS. It can be used as a marker to identify patients who should be screened for MetS and managed accordingly.

Key Words: androgenetic alopecia, baldness, metabolic syndrome

E-poster presented at the $39^{\text {th }}$ Annual Convention of the Philippine Dermatological Society, November 3-5, 2016, EDSA Shangri-La Hotel, Mandaluyong City, Philippines

Corresponding author: Leah Antoinette M. Caro-Chang, MD Section of Dermatology Department of Medicine Philippine General Hospital University of the Philippines Manila Padre Faura, Ermita, Manila 1000, Philippines Telephone: +632 5548400 local 5105/5106

Email: Imcaro@up.edu.ph

\section{INTRODUCTION}

\section{Description of the Conditions}

Androgenetic alopecia (AGA), occurring in both males and females, is the most common cause of hair loss affecting up to $80 \%$ of males by the age $80 .{ }^{1}$ The combination of a genetic predisposition and adequate circulating dihydrotestosterone (DHT) lead to miniaturization where there is gradual transformation of large terminal follicles to vellus ones. ${ }^{2}$

Metabolic syndrome is a combination of conditions that increase your risk for cardiovascular disease (CVD) and other health problems such as diabetes mellitus and cerebrovascular disease. It has also been linked to hypertension, prostate cancer, polycystic ovarian syndrome, among many others. ${ }^{3}$ 


\section{Significance of the Review}

The first study that explored the association between androgenetic alopecia and cardiovascular disease was by Cotton et al in 1972. More studies investigated the link between these disease entities. Decades later, a metaanalysis ${ }^{4}$ concluded that vertex baldness is associated with an increased risk of cardiovascular disease and this association depends on the severity. Subsequent studies demonstrated that androgenetic alopecia might also be associated with insulin resistance and diabetes mellitus, as well as abnormal lipid parameters and obesity. These findings led to researches exploring the connection between androgenetic alopecia and metabolic syndrome thereby providing a clue for underlying systemic diseases.

The pathophysiology behind the relationship between androgenetic alopecia and metabolic syndrome and its individual components remain under investigation. Studies implicate the role of androgens and insulin. There are two proposed mechanisms for hypertension in relation to androgen. First, androgens bind to androgen-mediators in arterial wall endothelium leading to the proliferation of smooth muscle cells in the vessels. Second, there may also be some binding to mineralocorticoid receptors. Interactions with either of these two receptors lead to high blood pressure. ${ }^{7}$

Insulin resistance plays a pathogenic role in metabolic syndrome but has been implicated in androgenetic alopecia as well. Insulin resistance contributes to miniaturization of hair follicles and the vasoactive substances related to the condition leads to microcirculatory disturbance, perifollicular vasoconstriction, and proliferation of smooth muscle cells in the vascular wall. ${ }^{7}$

Given the information, both the hair follicles and vascular endothelium are responsive to androgens and insulin predisposing patients to conditions that comprise the metabolic syndrome.

\section{Research Question}

Among patients with androgenetic alopecia, what are the odds of developing metabolic syndrome?

\section{METHODS}

\section{Search Strategy}

All observational studies exploring the relationship between androgenetic alopecia and metabolic syndrome were included. Inclusion criteria for cohort, case-control, and cross-sectional studies were the following: 1) available full-text was reported in or could be translated to English, 2) presence and severity of androgenetic alopecia were reported, 3) presence of metabolic syndrome (with reference for diagnosis) and its parameters were reported, and 4) raw data were available from which odds ratio can be computed.

The diagnosis of metabolic syndrome was either based on the parameters of the National Cholesterol Education Program Adult Treatment Panel III (NCEP ATPIII) that required three or more criteria to establish metabolic syndrome or the International Diabetes Federation that necessitated an abnormal waist circumference plus two other criteria. Some studies observed adjustments in waist circumference based on race while others adhered to the original cut-off values. A comparison of the two guidelines can be found in Appendix A.

\section{Electronic Searches}

The MEDLINE, Cochrane Library, TRIP, and HERDIN electronic databases were searched for articles covering January 1950 until 16 December 2016 using the medical subject headings "androgenetic alopecia" ("androgenic alopecia" or "baldness" or "pattern hair loss") and "metabolic syndrome" to identify observational studies that estimated the association between androgenetic alopecia and metabolic syndrome.

We also searched the Journal of the American Academy of Dermatology (JAAD) and Google scholar for relevant articles using the abovementioned keywords. Reference lists of identified studies were also perused for clinical trials and relevant reviews.

\section{Selection Criteria}

Studies were selected by the consensus of three independent review authors. Upon completion of searches, all articles were compiled for preliminary review. First, scanning of titles and abstracts was done for inclusion by two independent authors. Duplicate articles were identified. Full-text articles were retrieved if inclusion criteria were unclear or could not be identified by preliminary review. A third review author was consulted to resolve any discrepancies or disagreements between the two independent authors.

\section{Analysis and Appraisal of Data}

\section{Quality Assessment}

To assess the validity of studies, the Newcastle-Ottawa Scale for non-randomized studies in meta-analysis was used for evaluating the risk of bias of studies. ${ }^{8}$ An adaptation of the Newcastle Ottawa Scale ${ }^{9}$ was used to score the crosssectional studies. It has four items for selection, one item for comparability, and three items for outcome. Answers for each category that warranted a star were marked in the checklist. A total score of six or higher was considered good quality. ${ }^{4} \mathrm{~A}$ tabulation of the scores per criteria can be found in Appendix C.

Heterogeneity was assessed by visual inspection of forest plots and by determining $\mathrm{I}^{2}$ statistic. It was interpreted based on the Cochrane Handbook for Systemic Reviews of Interventions (Chapter 9, section 9.5).

For missing data of studies suspected with reporting biases, especially involving primary outcomes, authors were contacted. Both fixed and random effects were determined and compared for the studies displaying heterogeneity. 


\section{Data Extraction and Management}

For the included studies, two review authors obtained the following information: authors, year of publication, type of study, country where the study was conducted, number of participants, diagnoses of metabolic syndrome and criteria, methods and parameters of assessing baldness, and variables used in adjustment.

\section{Data Synthesis}

The pooled odds ratio (OR) and its 95\% confidence interval $(\mathrm{CI})$ were calculated using the Mantel-Haenszel method with the random effect model. Among-study variance was estimated using tau-squared $\left(\mathrm{Tau}^{2}\right)$. The chisquared $\left(\mathrm{Chi}^{2}\right)$ test for heterogeneity was also carried out. Statistical analyses were accomplished using Review Manager 5.3 software. Results were expressed as the number of events $(\mathrm{N})$ with $95 \% \mathrm{CI}$ unless otherwise stated. A p value of less than 0.05 was considered significant.

\section{Subgroup Analyses and Heterogeneity}

Subgroup analyses were done on outcomes of early-onset androgenetic alopecia among males, androgenetic alopecia among females, and severity of androgenetic alopecia for both males and females. Heterogeneity was visually assessed using the forest plot and objectively determined using the $\mathrm{I}^{2}$ statistic. For trials with high heterogeneity, possible reasons for such were explored. Data of trials not included in the meta-analysis were discussed separately.

\section{RESULTS}

\section{Results of the Search}

Figure 1 shows a flow chart of the study selection process. We identified a total of 1201 reports by searching databases. A total of 1161 studies were excluded based on title and abstract. Among these, 38 records were selected for further analyses after excluding duplicates across databases. Twelve (12) records were not available for full-text review, resulting to 26 studies for further assessment. Out of the 26, seven lacked pertinent data to answer the study objectives hence were omitted. The remaining 17 studies, fulfilling the inclusion criteria, were used for the qualitative analysis, 15 for the quantitative analysis. The two studies did not have sufficient data that could be used for computation but had information that could supplement the analyses. The 15 studies included in the various meta-analyses comprised data from a total of 7394 participants.

\section{Included Studies}

The 17 studies that were selected included 11 casecontrol studies, one prospective cohort, and five crosssectional studies. The studies were published between 2009 and 2016. Their characteristics are summarized in Table 1.

\section{Setting}

Eleven (11 studies) were conducted in Asia (Taiwan, Korea, India, and Tukey), two in Europe (Spain), three in Africa (Egypt), and one in South America (Mexico). The case-control studies were all hospital-based. One study (Gonzales-Gonzales et al) ${ }^{10}$ recruited cases via newspaper ads and had age-matched controls recruited in the hospital where the study was conducted. The cohort and crosssectional studies recruited patients from the community as part of other ongoing projects or programs.

\section{Participants}

The total number of participants for all studies was 7394. The age of the participants in the trials ranged from 18 years old to 95 years old. The mean proportion of males and females was approximately 6:1 (6454:1118). In all of case-control trials, participants with and without androgenetic alopecia were matched in terms of age and sex. Not all studies described control for other possible confounding factors. All of the participants were diagnosed with androgenetic alopecia clinically whether through photographs or actual evaluation.

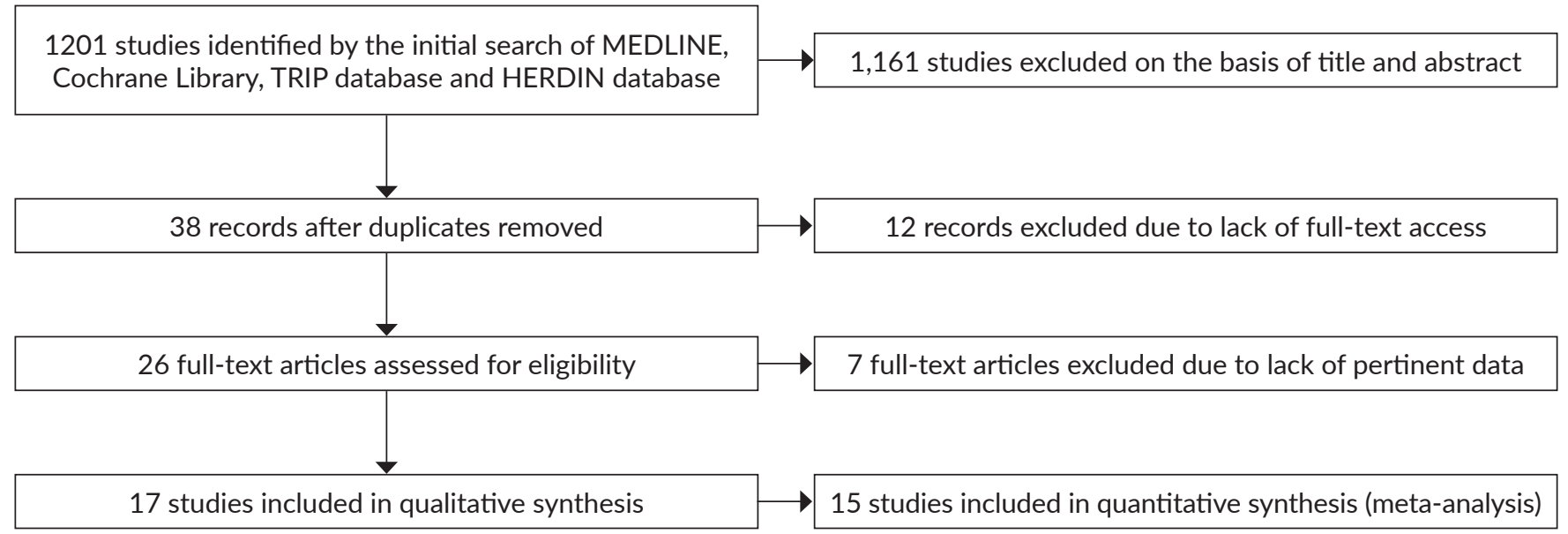

Figure 1. Flow diagram of study selection. 
Table 1. List of study participants

\begin{tabular}{|c|c|c|c|c|c|c|c|c|c|c|c|}
\hline Authors & Year & Study type & Country & Sex & $\begin{array}{l}\text { Total } \\
\text { (N) }\end{array}$ & $\begin{array}{l}\text { AGA } \\
(\mathrm{N})\end{array}$ & Classification & $\begin{array}{l}\text { Other } \\
\text { data }\end{array}$ & $\begin{array}{l}\text { MetS } \\
+ \text { AGA } \\
\text { (N) }\end{array}$ & Reference & Adjusted variables \\
\hline $\begin{array}{l}\text { Gonzales- } \\
\text { Gonzales } \\
\text { et al }\end{array}$ & 2009 & Case-control & $\begin{array}{l}\text { Mexico } \\
\text { Cases, } \\
\text { community; } \\
\text { Controls, } \\
\text { hospital } \\
\end{array}$ & M & 160 & 80 & $\begin{array}{l}\text { Hamilton- } \\
\text { Norwood }\end{array}$ & $\begin{array}{l}\text { Severity; } \\
\text { Vertex } \\
\text { baldness }\end{array}$ & 16 & IDF & $\begin{array}{l}\text { obesity, WHR, } \\
\text { BP, family history } \\
\text { (alopecia, obesity, } \\
\text { hypertension) }\end{array}$ \\
\hline Su and Chen & 2010 & $\begin{array}{l}\text { Cross- } \\
\text { sectional }\end{array}$ & $\begin{array}{c}\text { Taiwan } \\
\text { population- } \\
\text { based cross- } \\
\text { sectional survey }\end{array}$ & $M$ & 670 & 670 & $\begin{array}{l}\text { Hamilton- } \\
\text { Norwood }\end{array}$ & Severity & 111 & $\begin{array}{l}\text { NCEP } \\
\text { ATP III }\end{array}$ & $\begin{array}{l}\text { age, family history, } \\
\text { smoking status }\end{array}$ \\
\hline $\begin{array}{l}\text { Acibucu } \\
\text { et al }\end{array}$ & 2010 & Case-control & $\begin{array}{l}\text { Turkey } \\
\text { Cumhuriyet } \\
\text { University } \\
\text { Health Services } \\
\text { Practice and } \\
\text { Research } \\
\text { Hospital } \\
\end{array}$ & $M$ & 128 & 80 & $\begin{array}{l}\text { Hamilton- } \\
\text { Norwood }\end{array}$ & $\begin{array}{l}\text { Early- } \\
\text { onset }\end{array}$ & 20 & $\begin{array}{l}\text { NCEP } \\
\text { ATP III }\end{array}$ & age \\
\hline $\begin{array}{l}\text { Arias- } \\
\text { Santiago } \\
\text { et al }\end{array}$ & 2010 & Case-control & $\begin{array}{c}\text { Spain } \\
\text { University } \\
\text { hospital in } \\
\text { Granada }\end{array}$ & $\mathrm{M} / \mathrm{F}$ & 154 & 77 & $\begin{array}{l}\text { Ebling; } \\
\text { Ludwig }\end{array}$ & $\begin{array}{l}\text { Early- } \\
\text { onset; } \\
\text { Severity }\end{array}$ & 42 & $\begin{array}{l}\text { NCEP } \\
\text { ATP III }\end{array}$ & $\begin{array}{l}\text { weight, height, age, } \\
\text { BMI, mean time } \\
\text { with AGA, tobacco, } \\
\text { sedentarism, } \\
\text { medications }\end{array}$ \\
\hline Yi et al & 2012 & $\begin{array}{l}\text { Cross- } \\
\text { sectional }\end{array}$ & $\begin{array}{c}\text { Korea } \\
\text { Korean Genome } \\
\text { Epidemiology } \\
\text { Study }\end{array}$ & $\mathrm{M} / \mathrm{F}$ & 2884 & 2884 & $\begin{array}{l}\text { Hamilton- } \\
\text { Norwood; } \\
\text { Ludwig }\end{array}$ & Severity & 808 & $\begin{array}{l}\text { NCEP } \\
\text { ATP III }\end{array}$ & $\begin{array}{l}\text { age, family history, } \\
\text { smoking status }\end{array}$ \\
\hline Su et al & 2013 & $\begin{array}{c}\text { Prospective } \\
\text { cohort }\end{array}$ & $\begin{array}{l}\text { Taiwan } \\
\text { community- } \\
\text { based } \\
\text { integrated } \\
\text { screening } \\
\text { program }\end{array}$ & $\mathrm{M} / \mathrm{F}$ & 7126 & 7126 & $\begin{array}{l}\text { Hamilton- } \\
\text { Norwood; } \\
\text { Ludwig }\end{array}$ & Severity & $\begin{array}{l}\text { no raw } \\
\text { data }\end{array}$ & $\begin{array}{l}\text { NCEP } \\
\text { ATP III }\end{array}$ & $\begin{array}{l}\text { age, family history, } \\
\text { smoking status }\end{array}$ \\
\hline Vaya et al & 2014 & Case-control & $\begin{array}{c}\text { Spain } \\
\text { Quiron hospital }\end{array}$ & $M$ & 100 & 50 & $\begin{array}{l}\text { Hamilton- } \\
\text { Norwood }\end{array}$ & Severity & 5 & $\begin{array}{l}\text { NCEP } \\
\text { ATP III }\end{array}$ & $\begin{array}{l}\text { age, smoking status, } \\
\text { hypercholesterolemia } \\
\text { and treatment, } \\
\text { diabetes and } \\
\text { pharmacological } \\
\text { treatment, and obesity }\end{array}$ \\
\hline Bakry et al & 2014 & Case-control & $\begin{array}{l}\text { Egypt } \\
\text { Menoufiya } \\
\text { University } \\
\text { Hospital }\end{array}$ & $M$ & 200 & 100 & $\begin{array}{l}\text { Hamilton- } \\
\text { Norwood }\end{array}$ & Severity & 39 & $\begin{array}{l}\text { NCEP } \\
\text { ATP III }\end{array}$ & $\begin{array}{c}\text { family history of AGA, } \\
\text { grade of AGA, vertex } \\
\text { involvement, waist } \\
\text { circumference, insulin, } \\
\text { HDL, FBS, BP }\end{array}$ \\
\hline Banger et al & 2015 & Case-control & $\begin{array}{c}\text { India } \\
\text { Government } \\
\text { Medical College }\end{array}$ & M & 200 & 100 & $\begin{array}{l}\text { Hamilton- } \\
\text { Norwood }\end{array}$ & $\begin{array}{l}\text { Early- } \\
\text { onset; } \\
\text { Severity }\end{array}$ & 22 & $\begin{array}{l}\text { NCEP } \\
\text { ATP III }\end{array}$ & $\begin{array}{l}\text { age, onset of alopecia, } \\
\text { family history of AGA, } \\
\text { hypertension, and DM }\end{array}$ \\
\hline $\begin{array}{c}\text { Chakrabarty } \\
\text { et al }\end{array}$ & 2015 & Case-control & $\begin{array}{c}\text { India } \\
\text { Out-patient } \\
\text { trichology clinic } \\
\text { in Bengaluru }\end{array}$ & $M$ & 170 & 85 & $\begin{array}{l}\text { Hamilton- } \\
\text { Norwood }\end{array}$ & $\begin{array}{l}\text { Early- } \\
\text { onset; } \\
\text { Severity }\end{array}$ & 37 & $\begin{array}{l}\text { NCEP } \\
\text { ATP III }\end{array}$ & $\begin{array}{c}\text { age, height, } \\
\text { weight, BMI, waist } \\
\text { circumference, blood } \\
\text { pressure, blood } \\
\text { glucose, and lipid } \\
\text { parameters }\end{array}$ \\
\hline Ertas et al & 2015 & Case-control & $\begin{array}{l}\text { Turkey } \\
\text { Erciyes } \\
\text { University }\end{array}$ & $M$ & 68 & 51 & $\begin{array}{l}\text { Hamilton- } \\
\text { Norwood }\end{array}$ & $\begin{array}{l}\text { Early- } \\
\text { onset; } \\
\text { Severity; } \\
\text { Vertex } \\
\text { baldness }\end{array}$ & 25 & IDF & $\begin{array}{c}\text { age, gender, } \\
\text { biochemical measures, } \\
\text { hormone profiles } \\
\text { and traditional } \\
\text { cardiovascular risk } \\
\text { factors }\end{array}$ \\
\hline Gok et al & 2015 & Case-control & $\begin{array}{c}\text { Turkey } \\
\text { Haseki Training } \\
\text { and Research } \\
\text { Hospital }\end{array}$ & $M$ & 116 & 74 & $\begin{array}{l}\text { Hamilton- } \\
\text { Norwood }\end{array}$ & Severity & 11 & IDF & $\begin{array}{c}\text { onset and duration } \\
\text { of AGA, age, weight, } \\
\text { height, waist } \\
\text { circumference, BMI, } \\
\text { sports life, TG, total } \\
\text { cholesterol, HDL, } \\
\text { LDL, FBG and blood } \\
\text { pressure values } \\
\end{array}$ \\
\hline
\end{tabular}


(continued) Table 1. List of study participants

\begin{tabular}{|c|c|c|c|c|c|c|c|c|c|c|c|}
\hline Authors & Year & Study type & Country & Sex & $\begin{array}{l}\text { Total } \\
\text { (N) }\end{array}$ & $\begin{array}{l}\text { AGA } \\
\text { (N) }\end{array}$ & Classification & $\begin{array}{l}\text { Other } \\
\text { data }\end{array}$ & $\begin{array}{l}\text { MetS } \\
+ \text { AGA } \\
\text { (N) }\end{array}$ & Reference & Adjusted variables \\
\hline Rather et al & 2015 & Case-control & $\begin{array}{l}\text { India } \\
\text { Hospital in } \\
\text { Jammu and } \\
\text { Kashmir }\end{array}$ & $\mathrm{F}$ & 178 & 42 & Ludwig & Severity & 0 & $\begin{array}{l}\text { NCEP } \\
\text { ATP III }\end{array}$ & $\begin{array}{c}\text { age, height, } \\
\text { weight, BMI, waist } \\
\text { circumference, } \\
\text { blood pressure, } \\
\text { blood glucose, and } \\
\text { lipid parameters }\end{array}$ \\
\hline Agamia et al & 2016 & $\begin{array}{c}\text { Cross- } \\
\text { sectional }\end{array}$ & $\begin{array}{c}\text { Egypt } \\
\text { University of } \\
\text { Alexandria } \\
\text { Hospital }\end{array}$ & $M$ & 400 & 300 & $\begin{array}{l}\text { Hamilton- } \\
\text { Norwood }\end{array}$ & $\begin{array}{l}\text { Early- } \\
\text { onset; } \\
\text { Severity }\end{array}$ & 153 & $\begin{array}{l}\text { NCEP } \\
\text { ATP III }\end{array}$ & $\begin{array}{c}\text { age, family history } \\
\text { of AGA and BPH, } \\
\text { height, weight, BMI, } \\
\text { waist circumference, } \\
\text { blood pressure, } \\
\text { blood glucose, and } \\
\text { lipid parameters }\end{array}$ \\
\hline $\begin{array}{l}\text { El Sayed } \\
\text { et al }\end{array}$ & 2016 & Case-control & $\begin{array}{c}\text { Egypt } \\
\text { Dermatology } \\
\text { outpatient } \\
\text { clinics of } \\
\text { the National } \\
\text { Research Centre } \\
\text { and Ain-Shams } \\
\text { University } \\
\text { Hospitals }\end{array}$ & $\mathrm{F}$ & 90 & 45 & Ludwig & Severity & 31 & $\begin{array}{l}\text { NCEP } \\
\text { ATP III }\end{array}$ & age \\
\hline $\begin{array}{c}\text { Gopinath } \\
\text { and Upadya }\end{array}$ & 2016 & Case-control & $\begin{array}{c}\text { India } \\
\text { Kasturba } \\
\text { Medical College }\end{array}$ & $M / F$ & 170 & 85 & Norwood & $\begin{array}{l}\text { Early- } \\
\text { onset }\end{array}$ & 19 & IDF & age \\
\hline Park et al & 2016 & $\begin{array}{c}\text { Cross- } \\
\text { sectional }\end{array}$ & $\begin{array}{l}\text { Taiwan Wonju } \\
\text { Severance } \\
\text { Christian } \\
\text { Hospital } \\
\end{array}$ & $M / F$ & 1884 & 991 & BASP & Severity & 259 & $\begin{array}{l}\text { NCEP } \\
\text { ATP III }\end{array}$ & $\begin{array}{c}\text { family history, medical } \\
\text { history, smoking } \\
\text { status, alcoholic } \\
\text { intake, exercise }\end{array}$ \\
\hline
\end{tabular}

AGA - androgenetic alopecia; BMI - body mass index; BPH - benign prostatic hyperplasia; BASP - Basic and specific type; NCEP ATP - National Cholesterol Education Program (NCEP) Adult Treatment Panel III; IDF - International Diabetes Federation

\section{Outcome Detection}

In 13 of the 17 studies, metabolic syndrome was diagnosed using the NCEP ATP III criteria while four studies used the IDF. Only one study had a follow-up period as part of the protocol and it was five years. The method of assessing baldness varied, with a modified or simplified Hamilton scale being employed in most studies, the Ebling scale used in one study and the BASP in another. For those with female participants, the Ludwig classification was used.

Early-onset alopecia was specified in seven studies. This is defined as the onset of androgenetic alopecia before the age of 30 or 35 for majority of the studies. Twelve (12) studies further classified the severity of alopecia, with either Hamilton-Norwood IV or higher considered as severe alopecia. The two studies that focused on females classified severity according to the Ludwig classification with I being mild, II as moderate, and III as severe.

The diagnosis of participants with androgenetic alopecia was adjusted for several risk factors (age, smoking and alcoholic history, family history, etc.) in some studies, but the number of variables differed significantly. Several studies investigated the individual components of the metabolic syndrome and explored other parameters such as insulin resistance, inflammatory markers and presence of atheromatous plaques, as well as the presence of polycystic ovarian syndrome and benign prostatic hyperplasia.

\section{DISCUSSION}

\section{Association of Androgenetic Alopecia with Metabolic Syndrome}

Among the 17 studies, 13 studies ${ }^{7,10-21}$ had adequate data for this analysis. Two studies ${ }^{22,23}$ did not have data representing metabolic syndrome among those without androgenetic alopecia and focused on the severity of androgenetic alopecia and the development of metabolic syndrome. The study by Rather et $\mathrm{al}^{24}$ did not have any of their participants, both cases and controls, fulfill the criteria for metabolic syndrome, making it impossible to compute for odds ratio. Meanwhile, the cohort study by Su et $\mathrm{a}^{25}$ only provided the computed odds ratio but did not have raw data that could be included in the pooled analysis. Efforts were made to contact the author but he did not respond.

The meta-analysis of 13 studies ${ }^{7,10-21}$ with a total of 7394 participants demonstrated that the odds of developing metabolic syndrome are greater among those with androgenetic alopecia (OR 2.59, 95\% CI 1.51 to 4.44; $\mathrm{p}<0.0005 ; \mathrm{I} 2=86 \%)$ but with considerable heterogeneity (Figure 2). The results of Su et al's cohort study ${ }^{25}$ that had 7126 participants also confirmed this relationship (HR 2.40, 95\% CI 1.47-3.92; 95\% CI 1.22-3.31) with no report of heterogeneity. 


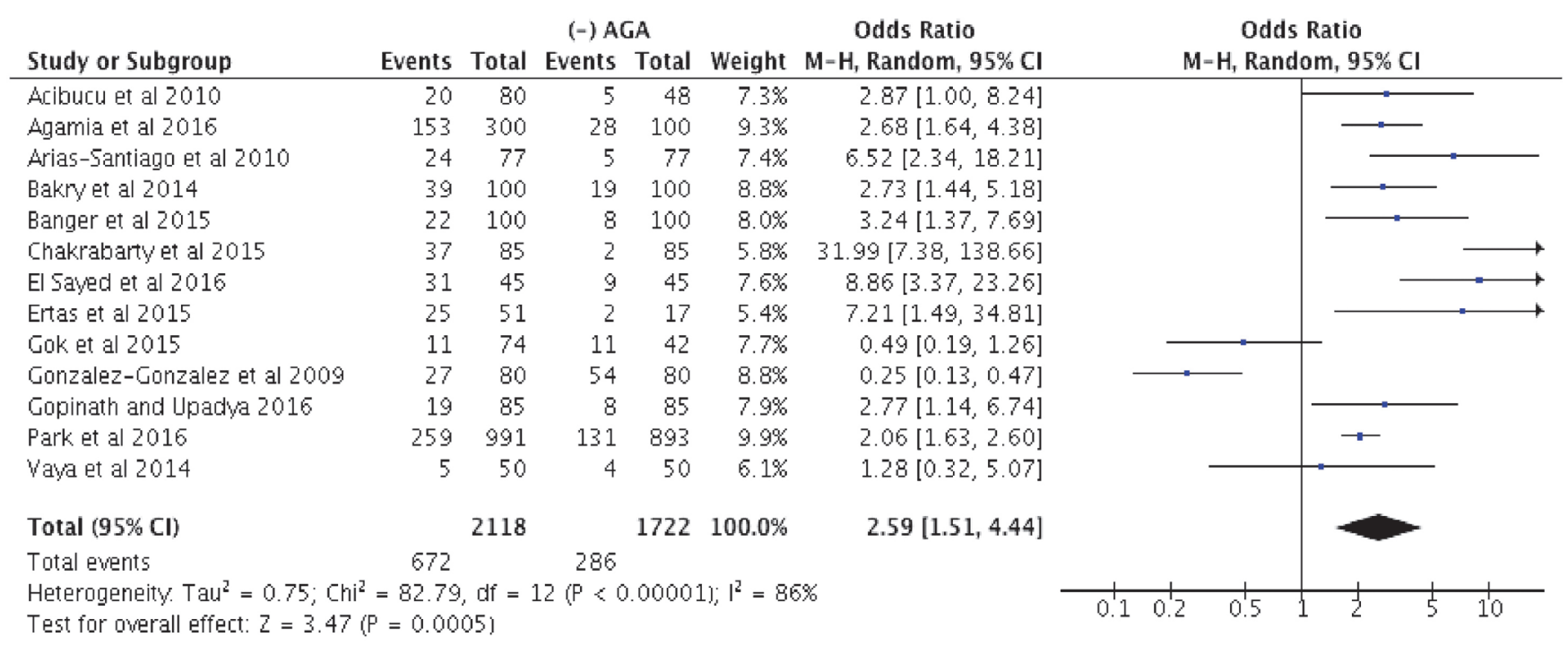

Figure 2. Forest plot showing the association between androgenetic alopecia and metabolic syndrome.

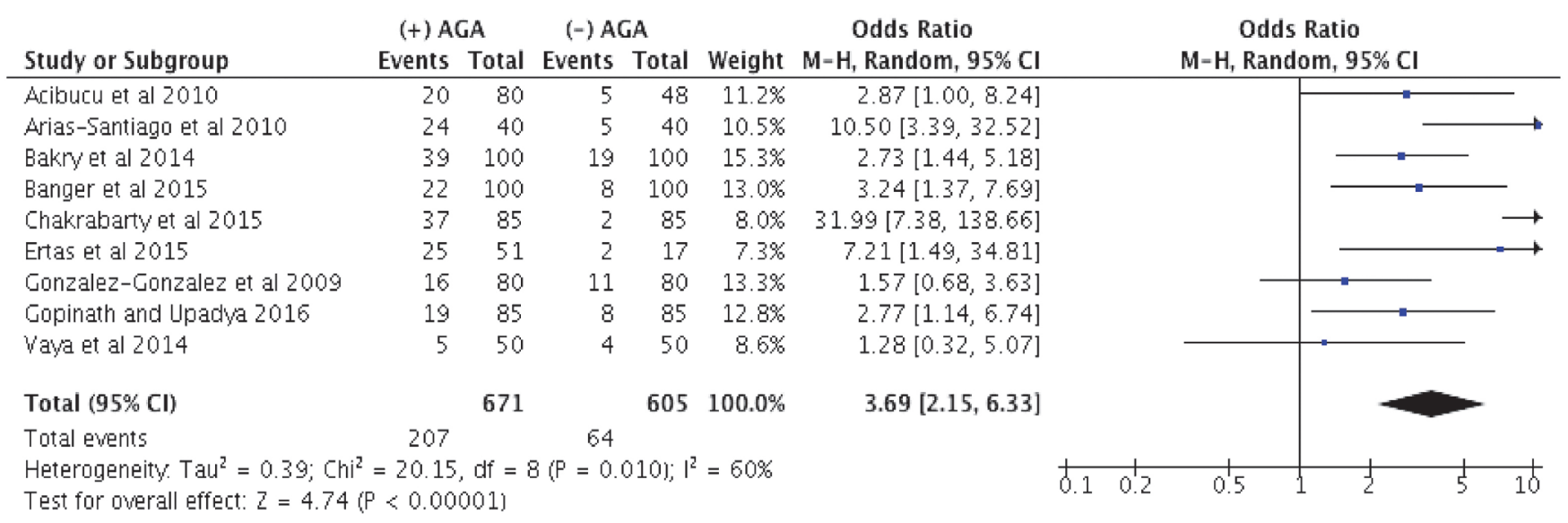

Figure 3. Forest plot showing the association between early-onset androgenetic alopecia (<35 years old) among males and metabolic syndrome.

Although the odds ratio pointed to a significant association between androgenetic alopecia and metabolic syndrome, there was considerable heterogeneity. According to the Cochrane Handbook, clinical and methodological diversity always occur in meta-analysis hence statistical heterogeneity is inevitable.

It must be noted that androgenetic alopecia is influenced by several factors - age, family history, and ethnicity. Age affects the development of both androgenetic alopecia and metabolic syndrome. This calculation did not control for age hence the outcomes may have been affected by this. Family history was also not controlled or considered as a possible confounding factor since not all studies provided data controlling for this. Moreover, ethnicity varied across studies and this variation affects the prognosis of both androgenetic alopecia and metabolic syndrome. Lastly, the differences in methodology across studies may have also contributed to the heterogeneity.

\section{Early-onset Androgenetic Alopecia among Males and Metabolic Syndrome}

Analysis of studies ${ }^{7,10-16,18}$ that specified early-onset androgenetic alopecia among males revealed that the odds of developing metabolic syndrome is greater if it occurs before the age of 35 (OR 3.69, 95\% CI 2.15 to 6.33; p<0.00001; $\mathrm{I}^{2}=60 \%$ ) with substantial heterogeneity (Figure 3 ).

The odds of developing metabolic syndrome among males with early-onset androgenetic alopecia are associated with metabolic syndrome. Although heterogeneity was decreased to $60 \%$, perhaps by controlling for age, there was still moderate heterogeneity that can be attributed to ethnicity and its influence on the course of androgenetic alopecia and metabolic syndrome.

\section{Androgenetic Alopecia among Females and Metabolic Syndrome}

Recently, more studies ${ }^{11,19,23}$ have investigated the association among females. The analysis showed that the 


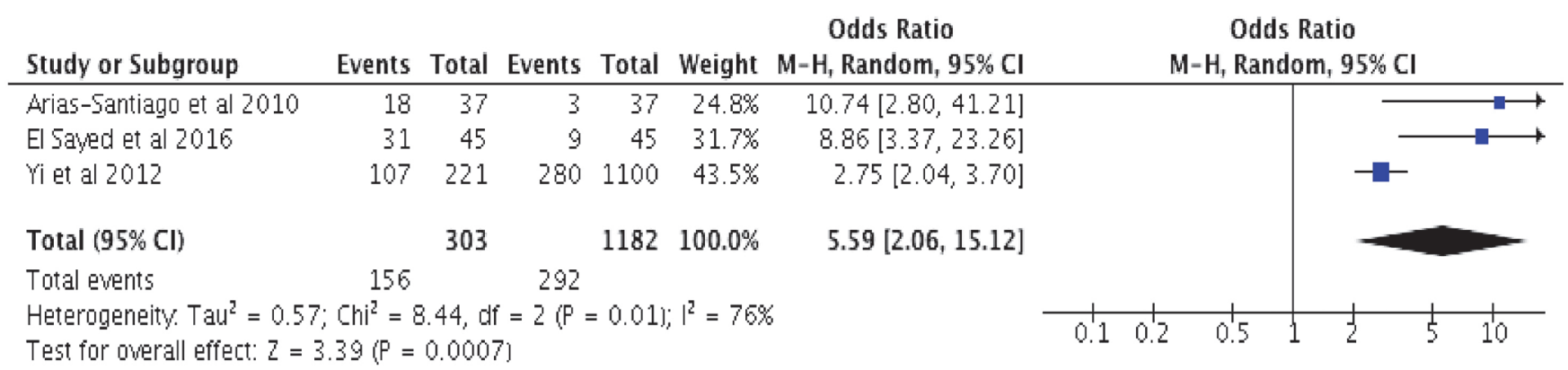

Figure 4. Forest plot showing the association between androgenetic alopecia among females and metabolic syndrome.

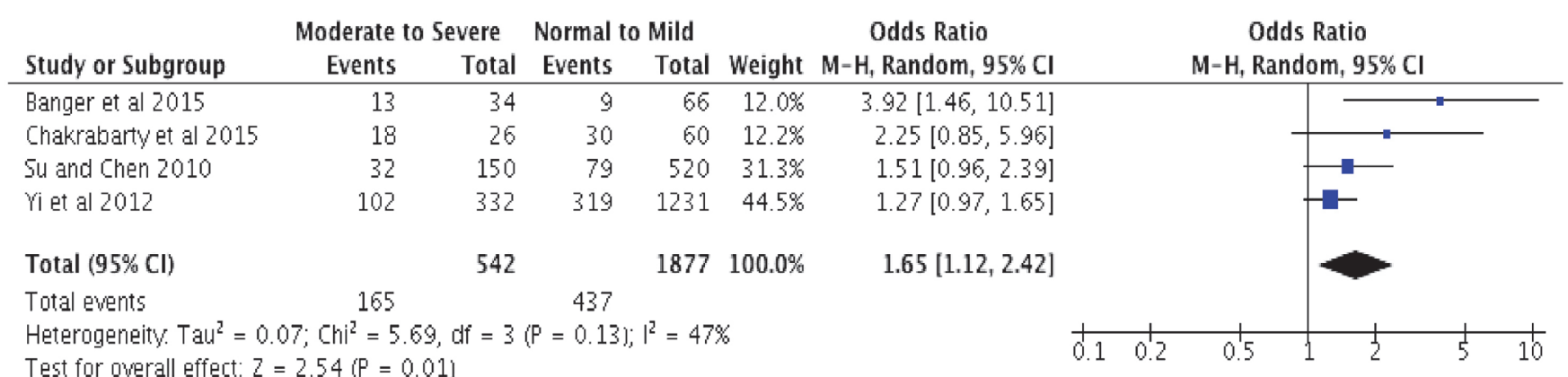

Figure 5. Forest plot showing the association between severity of androgenetic alopecia (Normal to Mild (Hamilton-Norwood I-III) vs. Moderate to Severe (Hamilton-Norwood IV or higher) among males and metabolic syndrome.

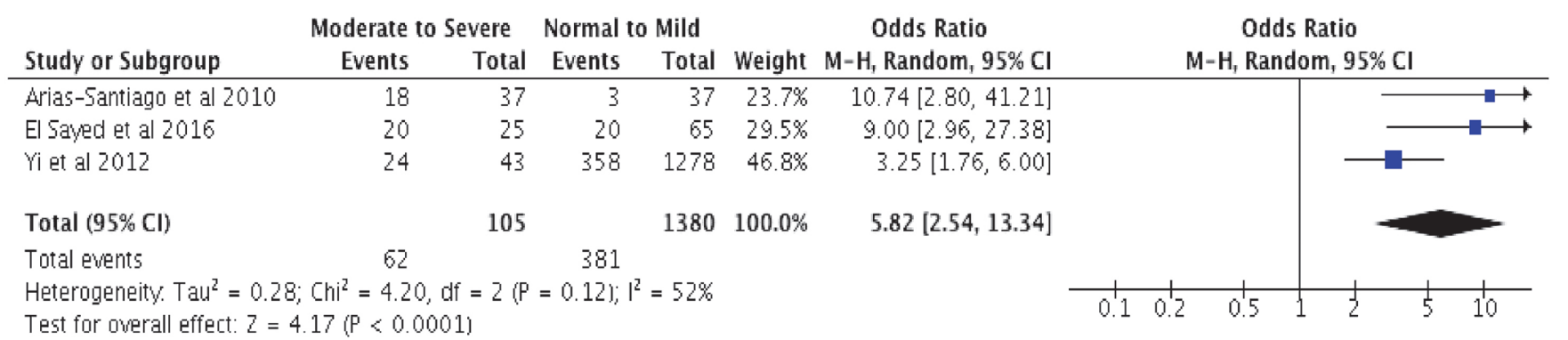

Figure 6. Forest plot showing the association between severity of androgenetic alopecia (Normal to Mild (Hamilton-Norwood I-III) vs. Moderate to Severe (Hamilton-Norwood IV or higher) among males and metabolic syndrome.

odds of developing metabolic syndrome are also present among females (OR 5.59, 95\% CI 2.06 to 15.12; p<0.0007; $\mathrm{I}^{2}=76 \%$ ) with considerable heterogeneity (Figure 4). The study by Rather, et al. ${ }^{24}$ could not be included in the meta-analysis because none of the participants fulfilled the criteria for metabolic syndrome, making it impossible to compute for odds ratio.

Again, this analysis limited to females yielded significant associations but age as confounding factor may have contributed to the higher heterogeneity. Moreover, the criteria for metabolic syndrome diagnosis were not uniform across studies.

\section{Severity of Androgenetic Alopecia and Metabolic Syndrome}

For males, this analysis was limited to studies that used Hamilton-Norwood for classification of alopecia severity. Two case-control studies ${ }^{14,15}$ and two crosssectional studies ${ }^{22,23}$ were utilized. A score of grade IV or higher was classified under moderate to severe whereas those with no alopecia up to grade III were counted under normal to mild. The pooled odds ratio was significant at 1.65 (95\% CI 1.12 to $2.42 ; \mathrm{p}=0.01 ; \mathrm{I}^{2}=47 \%$ ) with moderate heterogeneity (Figure 5). As with previous analyses, age was identified as a contributing factor to the moderate heterogeneity. Age influences the diagnoses of androgenetic alopecia and metabolic syndrome.

Three studies ${ }^{11,19,23}$ were included in analyzing severity of alopecia among females. Those with Ludwig score of I was considered mild and were grouped with those that did not have alopecia. Ludwig scores of II and III were combined. The pooled odds ratio was also significant at 5.82 (95\% CI 2.54 to $13.34 ; \mathrm{p}<0.00001 ; \mathrm{I}^{2}=52 \%$ ) with substantial heterogeneity (Figure 6). 


\section{CONCLUSION}

In the present meta-analysis, androgenetic alopecia was significantly associated with increased odds of metabolic syndrome and this was greater in early-onset androgenetic alopecia among males and the same trend was noted for females with androgenetic alopecia. For both sexes, greater severity of androgenetic alopecia also increased one's risk for metabolic syndrome.

\section{Agreement and Disagreement with Other Studies or Reviews}

Results of this study are consistent with meta-analyses done by $\mathrm{Wu}$ et $\mathrm{al}^{5}$ and Trieu and Eslick ${ }^{6}$. The study by Wu et $a 1^{5}$ was in Chinese and only the abstract was in English. Through four case-control studies and two crosssectional studies, they pooled a total of 4006 subjects. Meta-analysis showed that androgenetic alopecia was significantly correlated with metabolic syndrome (OR 2.70, 95\% CI 1.67 to $4.37 ; \mathrm{p}<0.01$ ) but there was no report of heterogeneity. Age, sex, and severity were not explored.

Trieu and Eslick ${ }^{6}$ investigated alopecia and its association with coronary heart disease and cardiovascular risk factors, one of them being metabolic syndrome. The subgroup analysis for this factor included seven studies with 1171 participants. An increased risk of metabolic syndrome was noted among patients with alopecia (OR 4.49, 95\% CI 2.36 to 8.53 ) but no note of $\mathrm{p}$ value. Similar to our findings, they also noted moderate heterogeneity $\left(\mathrm{I}^{2}=57.99 \%\right)$. It is also noteworthy to mention that they included studies where baldness in individuals was due to causes other than androgenetic alopecia, such as alopecia areata.

\section{Strengths and Limitations}

The strengths of the present meta-analysis were as follows. First, the present study included 11 case-control studies, one prospective cohort study, and five cross-sectional studies with a total of 7394 participants. The study also included participants from various ethnicities (Africa, Asia, Europe and South America). Extensive literature search was carried out through four databases as well as reference lists. Even though odds ratios were not provided in all studies, others were still considered provided it could be calculated from the data presented in order to ensure all relevant studies were included. Second, the study included meta-analysis on earlyonset androgenetic alopecia in males, androgenetic alopecia among females and severity of androgenetic alopecia in relation to metabolic syndrome for both males and females. These were all noted to be significant.

The present meta-analysis also had several limitations. First, we reviewed only English language reports for inclusion in this meta-analysis and might possibly have overlooked some non-English literature, which could have led to selection bias. The types of studies included inherent selection bias and a temporal relationship between androgenetic alopecia and metabolic syndrome cannot be elucidated. Our results may be affected by confounding factors such as other risk factors that may contribute to the diagnosis of androgenetic alopecia and metabolic syndrome (i.e. age, obesity, smoking status, and family history). Not all studies reported odd ratios, more so adjusted odd ratios hence these may have affected the results. Age is a very strong risk factor for both androgenetic alopecia and the various parameters of metabolic syndrome and false positive results are possible. However, most, if not all, of the casecontrol studies used aged-match controls alleviating the potential bias in the results due to this factor.

Heterogeneity was significant across studies, ranging from moderate to considerable. Although most studies used the Hamilton-Norwood scale for males and Ludwig for females, studies differed in terms of the number of evaluators, direct examination versus photographic examination, and the classification of severity of alopecia. The different diagnostic criteria for metabolic syndrome may have also contributed to the heterogeneity to some extent. Moreover, given the various components of the metabolic syndrome, confounding factors in its individual components may also have a role. Although several studies documented controlling for such confounding factors, several studies did not include these in their report. Lastly, although androgenetic alopecia may have similar mechanism between sexes and across persons, sex and ethnicity may also play a role in affecting the severity of alopecia and the various components measured in establishing the diagnosis of metabolic syndrome. With regard to sex, there was a noted decrease in heterogeneity when separate analyses were carried out for males and females compared to the overall pooled data. As for ethnicity, two studies adjusted waist circumference based on the WHO revisions for Asians whereas other studies retained the standard protocol.

\section{Implication for Practice}

Our study provides substantial evidence supporting the use of androgenetic alopecia in clinical settings as a visible marker to identify patients who are at an increased risk of metabolic syndrome. Specifically, males less than 35 years of age with at least grade III androgenetic alopecia (HamiltonNorwood classification) and those with grade IV or higher, regardless of age, should be monitored closely. Females, regardless of age but with Ludwig II or III patterned hair loss, are also at risk. Lifestyle modifications can be advised and anthropometrics should be taken. A good history with review of systems and physical examination may also aid in early detection. The utility of performing diagnostic tests in patients consulting for androgenetic alopecia have yet to be established and are left to the physician's discretion.

\section{Implication for Research}

Well-designed cohort studies with careful selection of participants to control for extraneous factors such as 
age, family history, and ethnicity should be carried out. Standardization of the classification systems in diagnosing and grading androgenetic alopecia as well as parameters for metabolic syndrome may minimize heterogeneity and strengthen the evidence of correlation between diseases. Follow up for development of related diseases will also provide vital information. Given the significance noted in early-onset androgenetic alopecia among males, studies focused on this population may also be pursued to provide local data. The paucity of data among females with androgenetic alopecia and metabolic syndrome as well as the associated diseases is another area worth exploring. Lastly, the pathophysiology of androgenetic alopecia and its association with metabolic syndrome still remains under investigation. Elucidating the mechanism of their relationship may provide diagnostic and therapeutic options, intervening early in the course of disease or even before complications arise.

\section{Statement of Authorship}

All authors approved the final version submitted.

\section{Author Disclosure}

All authors declared no conflicts of interest.

\section{Funding Source}

This paper was funded by the authors. No external funding agency.

\section{REFERENCES}

1. Rathnayake D, Sinclair R. Male androgenetic alopecia. Expert Opin Pharmacother. 2010;11(8):1295-304. doi: 10.1517/ 14656561003752730

2. Rebora A. Pathogenesis of androgenetic alopecia. J Am Acad Dermatol. 2004; 50: 777-9.

3. Grundy SM, Brewer HB Jr, Cleeman JI, Smith SC Jr, Lenfant C; American Heart Association; National Heart, Lung, and Blood Institute. Definition of metabolic syndrome: Report of the National Heart, Lung, and Blood Institute/American Heart Association conference on scientific issues related to definition. Circulation. 2004;109(3):433-8.

4. Yamada T, Hara K, Umematsu H, Kadowaki T. Male pattern baldness and its association with coronary heart disease : a meta-analysis. $\mathrm{Br}$ Med J Open. 2013;3: 1-8.

5. Wu D, Wu L, Yang Z. 雄激素性脱发与代谢综合征关系的meta 分析.J Zhejiang Univ Medical Sci. 2014;9.

6. Trieu N, Eslick GD. Alopecia and its association with coronary heart disease and cardiovascular risk factors : A meta-analysis. Int J Cardiol. 2014. 176: 687-95

7. Bakry O, Shoeib MA, El Shafiee M, Hassan A. Androgenetic alopecia, metabolic syndrome, and insulin resistance: Is there any association? A case-control study. Indian Dermatol Online J. 2014;5(3):276-81

8. Wells G, Shea B, O'Connell D, et al. The Newcastle-Ottawa Scale (NOS) for assessing the quality of nonrandomised studies in metaanalyses [Online]. Accessed December 20, 2016.Available from http://www.ohri.ca/programs/clinical_epidemiology/oxford.asp.

9. Herzog R1, Álvarez-Pasquin MJ, Díaz C, Del Barrio JL, Estrada JM, Gil Á. Are healthcare workers' intentions to vaccinate related to their knowledge, beliefs and attitudes? A systematic review. BMC Public Health. 2013;13:154. doi: 10.1186/1471-2458-13-154.
10. González-González JG1, Mancillas-Adame LG, Fernández-Reyes M, Gómez-Flores M, Lavalle-González FJ, Ocampo-Candiani J, et al. Androgenetic alopecia and insulin resistance in young men. Clin Endocrinol (Oxf). 2009;71(4):494-9. doi: 10.1111/j.13652265.2008.03508.x

11. Arias-Santiago S, Gutiérrez-Salmerón MT, Castellote-Caballero L, Buendía-Eisman A, Naranjo-Sintes R. Androgenetic alopecia and cardiovascular risk factors in men and women: A comparative study. J Am Acad Dermatol. 2010;63(3):420-9.

12. Acibucu F, Kayatas M, Candan F. The association of insulin resistance and metabolic syndrome in early androgenetic alopecia. Singapore Med J. 2010;51(12):931-6.

13. Vayá A, Sarnago A, Ricart JM, López V, Martínez-Triguero ML, Laiz B. Inflammatory markers and $\mathrm{Lp}$ (a) levels as cardiovascular risk factors in androgenetic alopecia. Clin Hemorheol Microcirc. 2016;61(3):471-7.

14. Chakrabarty S, Hariharan R. Association of Premature Androgenetic Alopecia and Metabolic Syndrome in a Young Indian Population. Int J Trichology. 2014;6(2):50-3.

15. Banger HS, Malhotra SK, Singh S, Mahajan M. Is Early Onset Androgenic Alopecia a Marker of Metabolic Syndrome and Carotid Artery Atherosclerosis in Young Indian Male Patients? Int J Trichology. 2015;7(4):141-7.

16. Ertas R, Orscelik O, Kartal D, Dogan A, Ertas SK, Aydogdu EG, et al. Androgenetic alopecia as an indicator of metabolic syndrome and cardiovascular risk. Blood Press. 2016;25(3):141-8. doi: 10.3109/08037051.2015.1111021

17. Ozbas Gok S, Akin Belli A, Dervis E. Is there really relationship between androgenetic alopecia and metabolic syndrome? Dermatol Res Pract. 2015;17(3):220-2.

18. Gopinath H, Upadya G. Metabolic syndrome in androgenic alopecia. Indian J Dermatol Venereol Leprol. 2016;82(4):404-8.

19. El Sayed MH, Abdallah MA, Aly DG, Khater NH. Association of metabolic syndrome with female pattern hair loss in women: A casecontrol study. Int J Dermatol. 2016;55(10):1131-7.

20. Park SY, Oh SS, Lee WS. Relationship between androgenetic alopecia and cardiovascular risk factors according to BASP classification in Koreans. J Dermatol. 2016;43(11):1293-1300.

21. Agamia NF, Abou Youssif T, El-Hadidy A, El-Abd A. Benign prostatic hyperplasia, metabolic syndrome and androgenic alopecia: Is there a possible relationship? Arab J Urol. 2016;14(2):157-62.

22. $\mathrm{Su} \mathrm{LH}, \mathrm{Chen} \mathrm{THH}$. Association of androgenetic alopecia with metabolic syndrome in men: A community-based survey. $\mathrm{Br} \mathrm{J}$ Dermatol. 2010;163(2):371-7.

23. Yi SM, Son SW, Lee KG, Kim SH, Lee SK, Cho ER, et al. Genderspecific association of androgenetic alopecia with metabolic syndrome in a middle-aged Korean population. Br J Dermatol. 2012;167(2):30613. doi: $10.1111 / \mathrm{j} .1365-2133.2012 .10978 . x$

24. Rather P, Naikoo N, Masood S, Akhtar S. Original research. Indian J Clin Exp Dermatology. 2015;1(1):9-13.

25. Su L-H, Chen L-S, Lin S-C, Chen H-H. Association of androgenetic alopecia with mortality from diabetes mellitus and heart disease. JAMA Dermatol. 2013;149(5):601-6. doi: 10.1001/jamadermatol.2013.130.

\section{APPENDICES}

Appendix A. Metabolic syndrome criteria

\begin{tabular}{lcc} 
& NCEP ATP III & IDF Guidelines \\
Waist circumference $(\mathrm{cm})$ & $>102 ;>88$ & $>94$ \\
Triglycerides $(\mathrm{mg} / \mathrm{dL})$ & Asian: $>90 ; 80$ & $>150$ \\
$\mathrm{HDL}-\mathrm{C}(\mathrm{mg} / \mathrm{dL})$ & $>150$ & $<40$ \\
$\mathrm{SBP}(\mathrm{mm} / \mathrm{Hg})$ & $<40$ & $>130$ \\
DBP $(\mathrm{mm} / \mathrm{Hg})$ & $>130$ & $>85$ \\
FBS $(\mathrm{mg} / \mathrm{dL})$ & $>85$ & $>100$ \\
\hline
\end{tabular}


Appendix B. Androgenetic alopecia severity grading. A. Hamilton-Norwood pattern of androgenetic alopecia for males. B. Ludwig pattern of androgenetic alopecia for females.
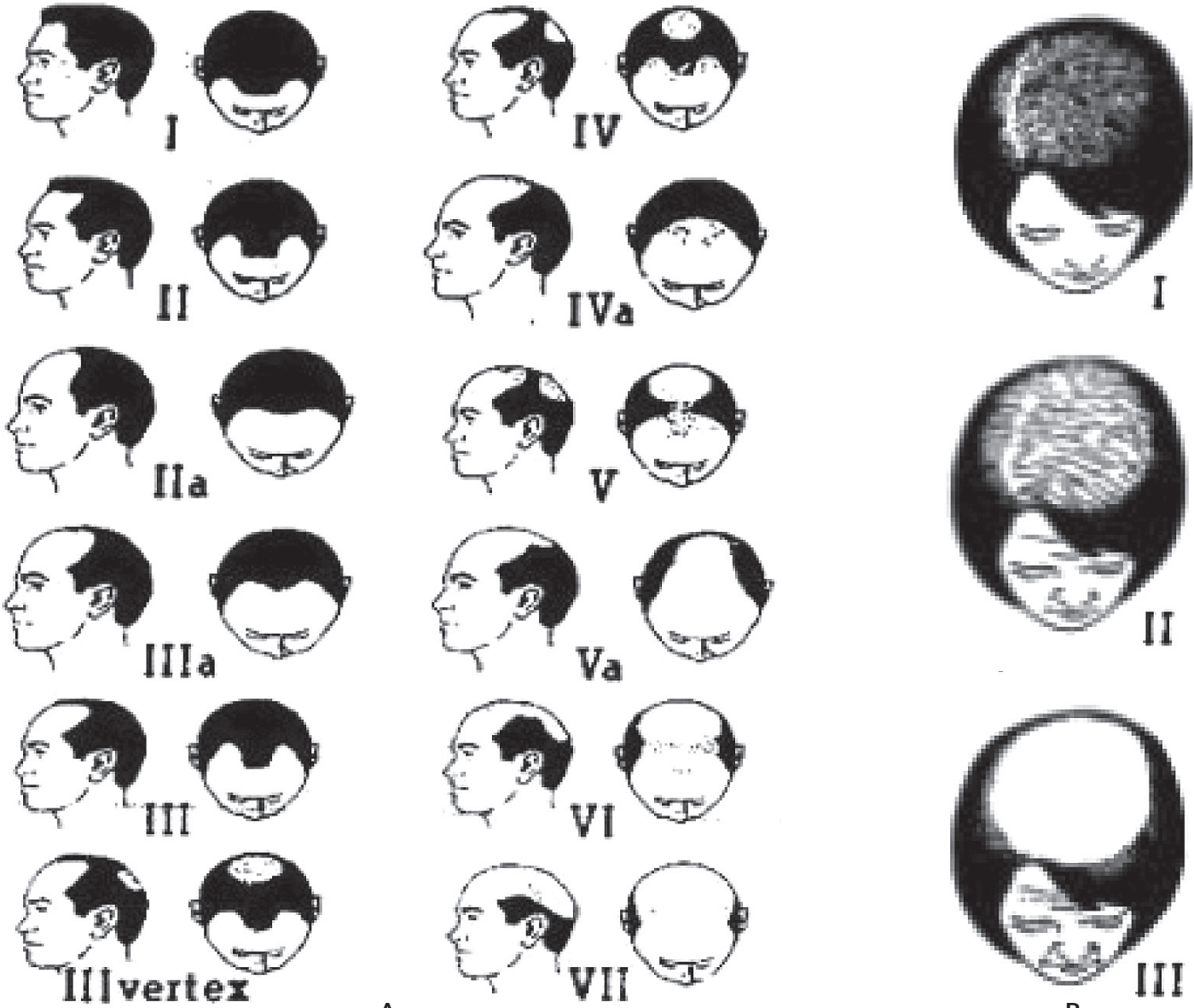

A

Appendix C. Summary of Newcastle-Ottawa quality assessment scale for observational studies with the review authors' judgements about each item

\begin{tabular}{|c|c|c|c|c|c|}
\hline & \multicolumn{5}{|c|}{ Case-control } \\
\hline & Selection & Comparability & Exposure & Total & Interpretation \\
\hline Gonzales-Gonzales et al 2009 & $* * *$ & * & $* *$ & 6 & $\checkmark$ \\
\hline Arias-Santiago et al 2010 & $* * *$ & $*$ & $* *$ & 6 & $\checkmark$ \\
\hline Acibucu et al 2010 & $* *$ & * & $* *$ & 5 & $?$ \\
\hline Bakry et al 2014 & $* * * *$ & * & $* *$ & 7 & $\checkmark$ \\
\hline Vaya et al 2014 & $* * *$ & * & $* *$ & 6 & $\checkmark$ \\
\hline Banger et al 2015 & $* * *$ & * & $* *$ & 6 & $\checkmark$ \\
\hline Chakrabarty et al 2015 & $* *$ & * & $* *$ & 5 & $?$ \\
\hline Ertas et al 2015 & $* * *$ & * & $* *$ & 6 & $\checkmark$ \\
\hline Gok et al 2015 & $* * *$ & * & $* *$ & 6 & $\checkmark$ \\
\hline Rather et al 2015 & $* * *$ & * & $* *$ & 6 & $\checkmark$ \\
\hline \multirow[t]{3}{*}{ El Sayed et al 2016} & $* * *$ & * & $* *$ & 6 & $\checkmark$ \\
\hline & \multicolumn{5}{|c|}{ Cohort } \\
\hline & Selection & Comparability & Outcome & Total & Interpretation \\
\hline \multirow[t]{3}{*}{ Su et al 2013} & $* * * *$ & $*$ & $* * *$ & 8 & $\checkmark$ \\
\hline & \multicolumn{5}{|c|}{ Cross-sectional } \\
\hline & Selection & Comparability & Outcome & Total & Interpretation \\
\hline Su and Chen 2010 & $* * * *$ & * & $* * *$ & 8 & $\checkmark$ \\
\hline Yi et al 2012 & $* * * *$ & * & $* * *$ & 8 & $\checkmark$ \\
\hline Agamia et al 2016 & $* * * *$ & * & *** & 8 & $\checkmark$ \\
\hline Gopinath and Upadya 2016 & $* * * *$ & * & $* * *$ & 8 & $\checkmark$ \\
\hline Park et al 2016 & $* * * *$ & * & $* * *$ & 8 & $\checkmark$ \\
\hline
\end{tabular}

